\title{
Interaction between ingested nutrients and gut endocrine cells in patients with irritable bowel syndrome (Review)
}

\author{
MAGDY EL-SALHY ${ }^{1,2}$, ODD HELGE GILJA ${ }^{2,3}$, DORIS GUNDERSEN ${ }^{4}$, \\ JAN G. HATLEBAKK ${ }^{2}$ and TRYGVE HAUSKEN ${ }^{2}$ \\ ${ }^{1}$ Section of Gastroenterology, Department of Medicine, Stord Helse-Fonna Hospital; ${ }^{2}$ Section of Gastroenterology, \\ Department of Clinical Medicine, University of Bergen; ${ }^{3}$ National Centre for Ultrasound in Gastroenterology, \\ Department of Medicine, Haukeland University Hospital, Bergen; \\ ${ }^{4}$ Department of Research, Helse-Fonna, Haugesund, Norway
}

Received December 31, 2013; Accepted February 10, 2014

DOI: $10.3892 /$ ijmm.2014.1811

\begin{abstract}
Several endocrine cell abnormalities have been reported in different segments of the gastrointestinal tract of patients with irritable bowel syndrome (IBS). These cells have specialized microvilli that project into the lumen; they function as sensors for the gut contents and respond to luminal stimuli (mostly ingested nutrients) by releasing hormones into the lamina propria, where they exert their effects via a paracrine/endocrine mode of action. Certain food items trigger the symptoms experienced by IBS patients, including those rich in fermentable oligo-, di- and monosaccharides, and polyols (FODMAPs). In this review, we present the argument that the effects of both FODMAPs and the proportional intake of proteins, fats and carbohydrates on IBS symptoms may be caused by an interaction with the gut endocrine cells. Since the gut hormones control and regulate gastrointestinal motility and sensation, this interaction may be responsible for abnormal gastrointestinal motility and the visceral hypersensitivity observed in these patients. There is no consistent evidence that IBS patients suffer from food allergy. The role of gluten intolerance in the development of IBS symptoms in these patients remains a matter of controversy. Individual guidance on food management, which includes restrictions in the intake of FODMAP-rich foods and testing diets with different proportions of proteins, fats and carbohydrates has been found to reduce the symptoms, improve the quality of life, and make the habitual diet of IBS patients more healthy.
\end{abstract}

Correspondence to: Professor Magdy El-Salhy, Section of Gastroenterology, Department of Medicine, Stord Helse-Fonna Hospital, Box 4000, 5409 Stord, Norway

E-mail: magdy.el-salhy@helse-fonna.no

Key words: allergy, cholecystokinin, diet, endocrine cells, enteric nervous system, gluten, minerals, polypeptide YY, probiotics, serotonin

\section{Contents}

1. Introduction

2. The role of diet in IBS

3. Diet management in IBS

4. Conclusion

\section{Introduction}

Irritable bowel syndrome (IBS) is a chronic functional gastrointestinal disorder with a worldwide prevalence of 10-20\% (1-15). The diagnosis of IBS is based mainly on the assessment of the symptoms, which are abdominal discomfort/pain, altered bowel habits and abdominal bloating/distension $(1,4)$. Patients with IBS can be subdivided into four subtypes according to the Rome III criteria and based on the stool pattern: diarrhea-predominant (IBS-D), constipation-predominant (IBS-C), mixed diarrhea and constipation (IBS-M) and unclassified IBS (U-IBS) $(16,17)$.

IBS is usually diagnosed in younger patients (i.e., $<50$ years of age) and is more common in women than in men $(3-6,8,9,11$, $12,14,15,18,19)$. Although IBS is not known to be associated with the development of serious disease or with excess mortality, it considerably reduces the quality of life of patients (1,19-21). In addition to the increased morbidity caused by IBS, this condition represents an economic burden to society as a result of the overconsumption of healthcare resources by and low productivity of IBS patients (22).

IBS patients often associate their symptoms with specific food items, such as milk and milk products, wheat products, caffeine, certain meats, cabbage, onion, peas/beans, hot spices, fried foods and smoked foodstuffs (23-25). However, surveys of the diets of IBS patients have failed to detect any differences in diet composition between IBS patients and the community as regards the intake of energy, carbohydrates, proteins and fats (26-32). However, a study on food intolerance and IBS found that $62 \%$ of the subjects had either limited or excluded food items from their daily intake, and $12 \%$ of these subjects had made such drastic changes in their diet that nutritional deficiencies could be foreseen in the long term (33). 
Certain studies have found IBS patients to be intolerant to various alcoholic beverages and generally have a low alcohol consumption $(23,29)$. However, other studies found that the alcohol intake in patients with IBS was the same as or higher than that in the background population $(30,31)$. The common belief among IBS patients is that lactose is the main cause of their symptoms, and consequently, they often reduce their intake of milk and milk products $(29,31,34,35)$. Milk and other dairy products are the most important dietary source of calcium, vitamin B2 (riboflavin) and phosphorus in the Western world (36). Thus, while IBS patients consume more products that are alternatives to milk, such as soy, rice and oat milk, they have a low daily intake of calcium, vitamin B2 and phosphorus (29).

IBS patients have a lower consumption of foods known to be rich in fermentable oligo-, di- and monosaccharides, and polyols (FODMAPs), such as spaghetti, pasta, rice, millet, couscous and buns than healthy controls (29). Moreover, IBS patients have lower consumptions of certain vegetables (raw vegetables, raw broccoli, paprika, onion, leeks, garlic, cabbage, tomatoes, mushrooms and green beans) (29). On the other hand, they consume more FODMAP-rich fruits and vegetables, such as grapes, pears, peaches, peas, mango, plums and melon (29).

The importance of dietary factors and the associations between diet and symptoms in IBS have been discussed in the literature $(23,37-41)$. The aim of this review was to shed light on the possible interaction between dietary intake and gut hormones, and the importance of diet management in reducing the symptoms and improving the quality of life of IBS patients.

\section{The role of diet in IBS}

The effect of diet on IBS symptoms may be attributed to the interaction between poorly absorbed carbohydrates/fiber and the intestinal bacterial flora, or between ingested nutrients and the gut neuroendocrine system, and food allergy or intolerance.

Interaction between poorly absorbed carbohydrates/fiber and the intestinal bacterial flora. Certain short-chain carbohydrates (FODMAPs) are poorly absorbed, resulting in a significant proportion of them reaching the distal small bowel and colon $(42,43)$, where they provide a substrate for bacterial fermentation. This results in the production of gas, with the consequent distension of the large intestine and increased intraluminal pressure. FODMAPs include fructose, lactose, sugar alcohols (sorbitol, maltitol, mannitol, xylitol and ismalt), fructans and galactans. Fructose and lactose are present in apples, pears, watermelon, honey, fruit juices, dried fruits, as well as milk and milk products. Polyols are used in low-calorie food products. Galactans and fructans are present in wheat, rye, garlic, onions, legumes, cabbage, artichokes, leeks, asparagus, lentils, inulin, soy, Brussels sprouts and broccoli $(39,40,44)$. A low intake of FODMAPs has been found to reduce the gastrointestinal symptoms in patients with IBS $(42,43,45,46)$.

Increasing the intake of dietary fiber is a standard recommendation for patients with IBS (47). However, in clinical practice, increased fiber intake in these patients has been shown to increase the symptoms of abdominal pain, bloating and distension. The examination of the effects of fiber intake on IBS symptoms has revealed that increased fiber intake does not improve symptoms compared with a placebo or a low-fiber diet (47). However, it has been reported that the intake of soluble fiber is effective in improving overall IBS symptoms relative to consuming insoluble fiber (47-50).

The effects of FODMAPs and fiber on IBS symptoms are strongly associated with the intestinal flora. The dominance of Clostridium spp. in the intestinal flora, which break down FODMAPs and fiber, results in gas production, with a consequent increase in the distension of the large intestine, causing abdominal discomfort or pain. Food supplements with beneficial bacteria, such as Lactobacillus spp. and Bifidobacterium spp. would result in a greater tolerance to both FODMAPs and fiber, since these bacteria do not produce gas on fermenting carbohydrates. It has been reported that the intestinal flora of IBS patients comprise fewer Lactobacillus spp. and Bifidobacterium spp. than the flora of healthy individuals $(51,52)$.

Interaction between ingested nutrients and the gut neuroendocrine system. The gut endocrine cells are spread between the epithelial cells of the mucosa facing the gut lumen $(1,53)$. They are present in all the segments of the gastrointestinal tract apart from the esophagus (1). There are several different populations of gut endocrine cells $(22,32,53-55)$; the distribution, functions and modes of action of the most important types have been reported previously $(22,32,53,56-68)$. Some of the different endocrine cell types are located only in specific areas of the gut, while others are found throughout the gut (53-55). Thus, serotonin- and somatostatin-secreting cells are found throughout the gastrointestinal tract, while those producing ghrelin and gastrin are found in the stomach; those producing secretin, cholecystokinin (CCK), gastric inhibitory peptide (GIP) and motilin are found in the upper small intestine, and those producing polypeptide YY (PYY), pancreatic polypeptide (PP) and enteroglucagon are located in the lower small intestine and large intestine (53-55). These cells have specialized microvilli that project into the lumen and function as sensors for the gut contents (mostly for nutrients), and respond to luminal stimuli by releasing their hormones into the lamina propria (Fig. 1) (69-81). The gut intraluminal contents of carbohydrates, proteins and fats triggers the release of the different signaling substances (i.e., hormones) from the gut endocrine cells $(1,53)$. These signaling substances may exert their actions locally on nearby structures (paracrine mode) or by entering the circulating blood and reaching distant targets (endocrine mode) (82). The gut endocrine cells interact and integrate with each other, and with the enteric nervous system (ENS) and the afferent and efferent nerve fibers of the autonomic nervous system and the central nervous system (CNS) $(22,53,59,83)$. In doing so, they regulate several functions of the gastrointestinal tract, including visceral sensation, motility, secretion, absorption, local immune defense and food intake $(22,53-55,83)$.

Several abnormalities in the gut endocrine cells have been described in IBS patients (84-100), as summarized in Table I and illustrated in Figs. 2 and 3. The etiology of these abnormalities in sporadic (non-specific) IBS patients can be genetically inherited and/or caused by environmental factors. A genetic etiology is supported by the familial aggregation of IBS and the results of twin studies (101-111). Alternatively, endocrine cells have a rapid turnover, and it is possible that factors related 
A

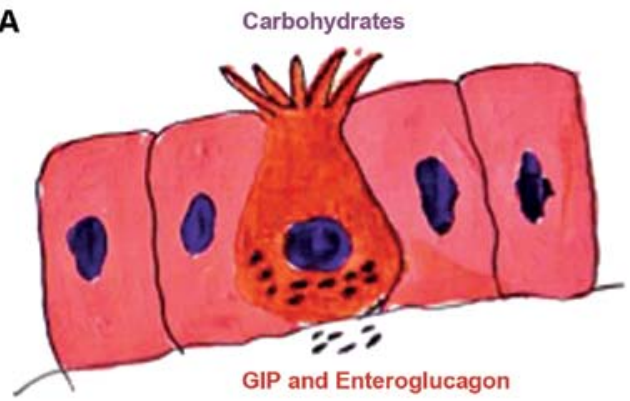

B

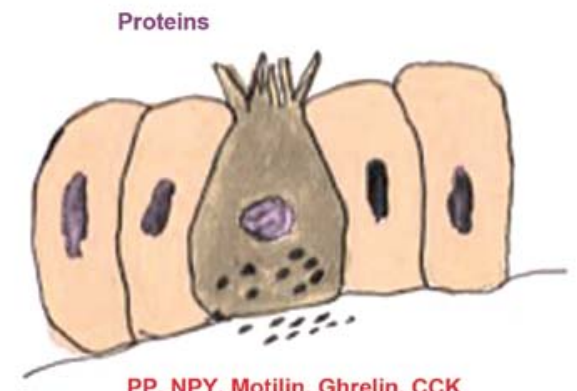

PP, NPY, Motilin, Ghrelin, CCK

\section{C}

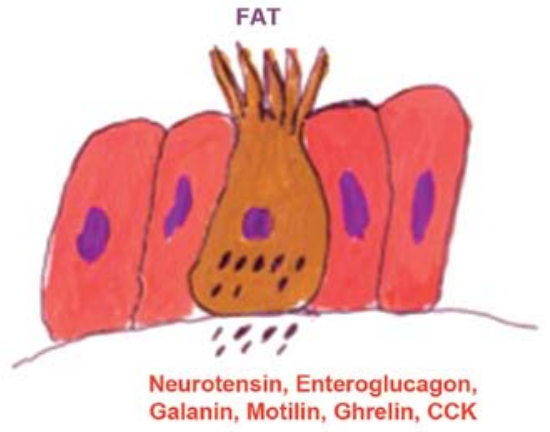

Figure 1. The gut hormones released into the interstitial fluid of the lamina propria in response to intraluminal nutrient content vary according to the proportions of (A) carbohydrates, (B) proteins and (C) fats. These hormones may act in an endocrine/paracrine manner or as neurotransmitters/neuromodulators of neurons in the ENS.

to luminal content, such as diet or bacterial flora can provoke an increase or decrease in the endocrine cell population $(54,55)$. In post-infectious IBS (PI-IBS), the abnormalities in gut endocrine cells may be the result of endocrine/immune interactions (i.e., the endocrine/immune axis), which are in turn caused by low-grade inflammation following gastroenteritis in predisposed individuals $(112,113)$.

As indicated in Table I, gastrointestinal hormone release is triggered by the intraluminal contents of nutrients; thus, the release of ghrelin, CCK and PYY is triggered by proteins and fat, and ghrelin release is suppressed by the presence of carbohydrates. Consequently, while a diet that is poor in fat, proteins and carbohydrates would aggravate the symptoms in patients with IBS-D, a diet containing low levels of fat and proteins and high levels of carbohydrates would worsen the symptoms in patients with IBS-C. In patients with PI-IBS, the symptoms would be worsened by food rich in proteins and fat.

In IBS patients, the gut endocrine cells may be responsible for the abdominal pain/discomfort resulting from the aforemen-
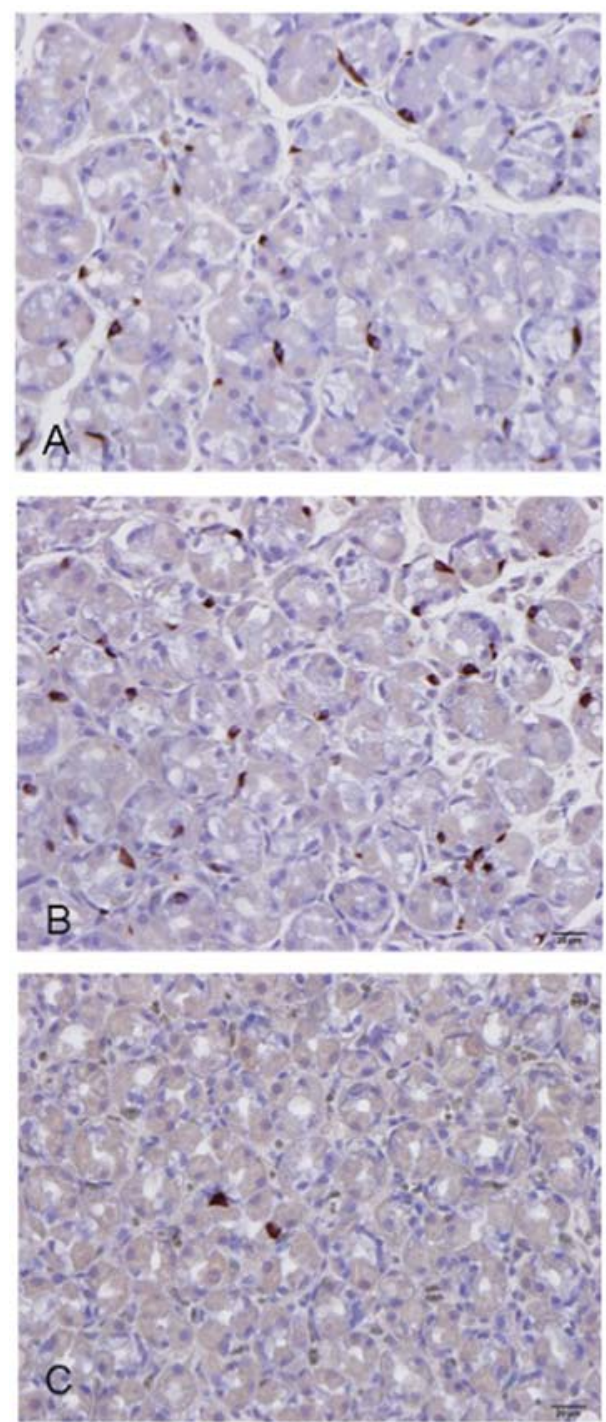

Figure 2. Ghrelin in the oxyntic mucosa of (A) a healthy subject, (B) a patient with diarrhea-predominant IBS (IBS-D), and (C) a patient with constipationpredominant IBS (IBS-C).

tioned gas production and consequent increase in intraluminal pressure and large-intestinal distension following the breakdown of FODMAPs and fibers by the intestinal bacterial flora. An increase in the intraluminal pressure would possibly result in the release of serotonin and substance $\mathrm{P}$ into the interstitial fluid. Serotonin activates the submucosal sensory branch of the ENS, which conveys the sensation to the CNS, possibly causing the sensation of abdominal pain/discomfort $(114,115)$. Furthermore, serotonin controls gastrointestinal motility and chloride secretion via interneurons and motor neurons, which may result in disturbances in both motility and gastrointestinal secretion $(114,115)$.

Food allergy or intolerance. There is neither consistent evidence for an allergic response nor documented evidence for intolerance to a specific food in IBS (1,116-122). Although a food allergy mediated by mucosal mechanisms has been suggested for IBS $(123,124)$, these mechanisms may play a role in only a subset of patients who may have atopy or PI-IBS $(1,123,125)$. Different 
Table I. Summary of the abnormalities in the endocrine cell densities in different segments of the gastrointestinal tract of IBS patients, and the factors responsible for the release of gut hormones and the functions of these hormones.

\begin{tabular}{|c|c|c|c|c|c|}
\hline Gut segment & $\begin{array}{l}\text { Endocrine } \\
\text { cell type }\end{array}$ & Released by & Functions & IBS-D & IBS-C \\
\hline \multirow[t]{4}{*}{ Stomach } & Ghrelin & $\begin{array}{l}\text { Protein and fat ingestion. } \\
\text { Suppressed by carbohydrate } \\
\text { ingestion. }\end{array}$ & $\begin{array}{l}\text { Increases gastric and intestinal } \\
\text { motility, and stimulates appetite } \\
\text { and food intake. }\end{array}$ & High & Low \\
\hline & Serotonin & $\begin{array}{l}\text { Adrenaline, acetylcholine, } \\
\text { acidification, and increased } \\
\text { intraluminal pressure. }\end{array}$ & $\begin{array}{l}\text { Activates the submucosal } \\
\text { sensory branch of the ENS, } \\
\text { inhibits gastric emptying, } \\
\text { stimulates colonic motility, } \\
\text { and accelerates small- and } \\
\text { large-intestinal transit. }\end{array}$ & Normal & High \\
\hline & Gastrin & $\begin{array}{l}\text { Intraluminal peptides, } \\
\text { amino acids, calcium, } \\
\text { amines, low pH, and } \\
\text { prostaglandins. Release } \\
\text { inhibited by somatostatin. }\end{array}$ & $\begin{array}{l}\text { Stimulates gastric acid secretion } \\
\text { and histamine release, and } \\
\text { stimulates contraction of } \\
\text { the LES and antrum. }\end{array}$ & High & High \\
\hline & Somatostatin & $\begin{array}{l}\text { Meal and acidification } \\
\text { of the stomach. }\end{array}$ & $\begin{array}{l}\text { Inhibits gut exocrine and } \\
\text { neuroendocrine secretion, and } \\
\text { inhibits intestinal contraction. }\end{array}$ & Low & Low \\
\hline \multicolumn{6}{|c|}{ Small intestine } \\
\hline \multirow[t]{4}{*}{ Duodenum } & CCK & Intraluminal protein and fat. & $\begin{array}{l}\text { Stimulates pancreatic exocrine } \\
\text { secretion and growth, regulates } \\
\text { food intake, inhibits gastric } \\
\text { emptying, and stimulates } \\
\text { gallbladder contraction and } \\
\text { intestinal motility. }\end{array}$ & Low & Normal \\
\hline & Secretin & $\begin{array}{l}\text { Acidification of the intestinal } \\
\text { contents. }\end{array}$ & $\begin{array}{l}\text { Stimulates pancreatic bicarbonate } \\
\text { and fluid secretion; inhibits } \\
\text { gastric emptying; inhibits } \\
\text { contractile activity of the small } \\
\text { and large intestines. }\end{array}$ & Low & Normal \\
\hline & GIP & $\begin{array}{l}\text { Intraluminal glucose; } \\
\text { amino acids and fat. }\end{array}$ & Inhibits gastric acid secretion. & Low & Low \\
\hline & Somatostatin & $\begin{array}{l}\text { Intraluminal glucose; } \\
\text { amino acids and fat. }\end{array}$ & Inhibits gastric acid secretion. & Low & Low \\
\hline \multirow[t]{2}{*}{ Ileum } & Serotonin & $\begin{array}{l}\text { Intraluminal glucose; } \\
\text { amino acids and fat. }\end{array}$ & Inhibits gastric acid secretion. & Low & Low \\
\hline & PYY & Protein- and fat-rich meals. & $\begin{array}{l}\text { Delays gastric emptying, } \\
\text { stimulates the absorption of } \\
\text { water and electrolytes; major } \\
\text { mediator of the ileal brake. }\end{array}$ & Normal & High \\
\hline \multicolumn{6}{|c|}{ Large intestine } \\
\hline \multirow[t]{2}{*}{ Colon } & Serotonin & Protein- and fat-rich meals. & $\begin{array}{l}\text { Delays gastric emptying, } \\
\text { stimulates the absorption of } \\
\text { water and electrolytes; major } \\
\text { mediator of the ileal brake. }\end{array}$ & Low & Low \\
\hline & PYY & Protein- and fat-rich meals. & $\begin{array}{l}\text { Delays gastric emptying, } \\
\text { stimulates the absorption of } \\
\text { water and electrolytes; major } \\
\text { mediator of the ileal brake. }\end{array}$ & Low & Low \\
\hline
\end{tabular}


Table I. Continued.

\begin{tabular}{|c|c|c|c|c|c|}
\hline Gut segment & $\begin{array}{l}\text { Endocrine } \\
\text { cell type }\end{array}$ & Released by & Functions & IBS-D & IBS-C \\
\hline \multirow[t]{3}{*}{ Rectum } & PYY & Protein- and fat-rich meals. & $\begin{array}{l}\text { Delays gastric emptying, } \\
\text { stimulates the absorption of } \\
\text { water and electrolytes; major } \\
\text { mediator of the ileal brake. }\end{array}$ & Low & Low \\
\hline & Enteroglucagon & $\begin{array}{l}\text { Intraluminal carbohydrates } \\
\text { and fat. }\end{array}$ & $\begin{array}{l}\text { Inhibits gastric and pancreatic } \\
\text { secretion, reduces gastric motility, } \\
\text { and has also some incretin effect. }\end{array}$ & Low & Low \\
\hline & Somatostatin & Protein- and fat-rich meals. & $\begin{array}{l}\text { Delays gastric emptying, } \\
\text { stimulates the absorption of } \\
\text { water and electrolytes; major } \\
\text { mediator of the ileal brake. }\end{array}$ & High & High \\
\hline
\end{tabular}

IBS, irritable bowel syndrom; IBS-D, diarrhea-predominant IBS; IBS-C, constipation-predominant IBS; LES, lower esophageal sphincter; GIP, gastric inhibitory peptide.
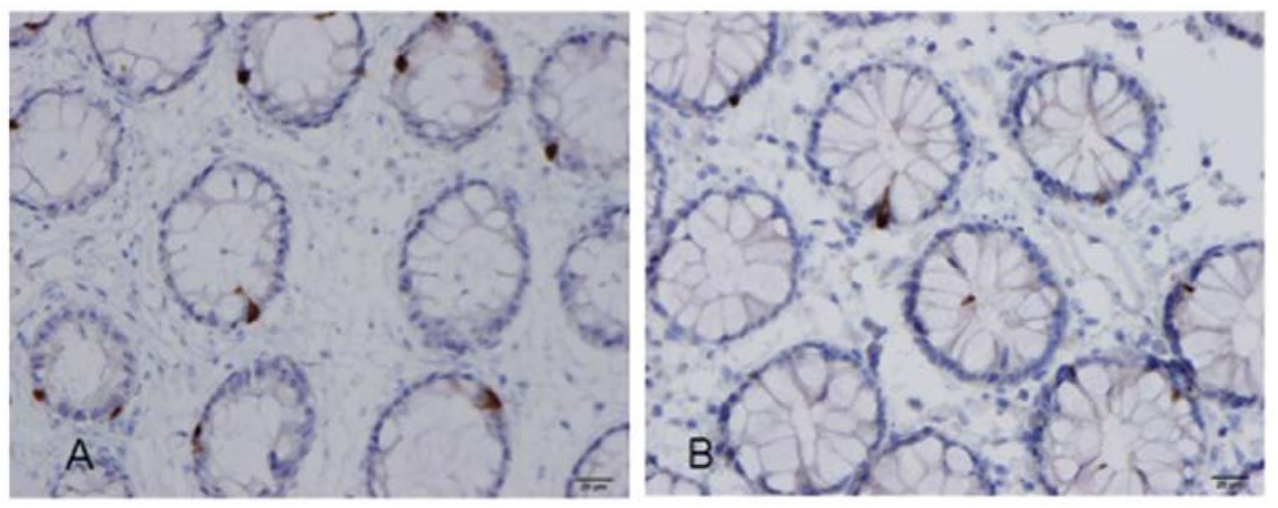

Figure 3. Polypeptide YY (PYY)-immunoreactive cells in the colon of (A) a healthy subject and (B) a patient with irritable bowel syndrome (IBS).

classes of antibodies ( $\mathrm{IgG})$ have been implicated in food-related allergies in IBS $(126,127)$. The results of studies on this subject are controversial, possibly sicne the tests used are not sufficiently sensitive or specific $(31,116,117,123,124,128-133)$.

The association between IBS and celiac disease (CD) has drawn much attention of late. The breadth of the spectrum of symptoms in IBS means that there is the potential for overlap with CD symptomatologies. Thus, patients with CD presenting with relatively vague abdominal symptoms can be diagnosed as having IBS $(39,40)$. Furthermore, the symptoms of both IBS and CD patients are triggered by the ingestion of wheat products. The reported prevalence of CD in IBS varies between 0.04 and $4.7 \%$ (134-144). It has been suggested that IBS patients with wheat intolerance and who carry the genotype associated with CD (HLA DQ2 or DR3), but do not have typical serological markers or changes in small-intestine histology exhibit other immunological evidence of gluten reactivity and response to a gluten-free diet (145).

The augmentation of IBS symptoms by the ingestion of wheat products has been attributed to the content of the sugar polymers, fructans and galactans $(38,146)$. In clinical practice, some IBS patients describe a reduction in symptoms upon eating a gluten-free diet. Although this has been dismissed by clinicians as a placebo effect, there is emerging new data regarding non-celiac gluten sensitivity (147). The existence of non-celiac gluten intolerance has been demonstrated by a double-blinded, randomized, placebo-controlled rechallenge trial (148). However, the diets of the subjects in that study excluded wheat products, which contain gluten, as well as fructans and galactans. A recent placebo-controlled, cross-over study found no evidence of the specific effects of gluten in non-celiac gluten sensitivity (149). Thus, the role of gluten intolerance in IBS has yet to be clarified, and further studies are required.

\section{Diet management in IBS}

It is clear that IBS patients need guidance on diet management. Providing IBS patients with diet guidance has been found to reduce symptoms and to improve their quality of life $(29,150)$. Furthermore, this guidance leads IBS patients to consume a more adequate diet in terms of the levels of vitamins and minerals, and makes them aware of all FODMAP-rich foods, the consumption of which they should either avoid or reduce. They also consume foods supplemented with Lactobacillus spp. 
and Bifidobacterium spp., which increase their tolerance to FOODMAPs (29).

Diet guidance should be individualized, since IBS patients have different tolerances to various FODMAP-rich foods, possibly due to differences in their intestinal flora. The aim of diet guidance should be to provide information about FODMAPs and their role in the symptoms of individual patients, and to instruct them to avoid such foods. Moreover, the effects of the proportional intakes of protein, fats and carbohydrates on their symptoms should be examined. In clinical practice, we have found that reducing the carbohydrate or fat intake and increasing the protein intake improves the symptoms in certain patients. In addition, IBS patients should be encouraged to consume foods that are supplemented with Lactobacillus spp. and Bifidobacterium spp. Other lifestyle factors, such as regular exercise and regular intake of probiotics, may augment the effect of diet management (151).

\section{Conclusion}

Diet triggers symptoms in IBS patients, possibly as a result of interactions with the gut endocrine cells, which are defective in IBS patients. The effects of the food content of FODMAPs and fiber on IBS symptoms are possibly mediated through gut endocrine cells. FODMAPs in the diet increase the osmotic pressure and provide a substrate for bacteria fermentation and gas production in the large intestine, resulting in abdominal distension. The increase in intestinal pressure may cause the release of serotonin and substance $\mathrm{P}$, which in turn may result in the sensation of abdominal discomfort or pain. The protein, fat and carbohydrate content of ingested foods determine the amount and type of gut hormones released, which will in turn regulate and control gastrointestinal motility and sensation, that have been reported to be abnormal in IBS patients (152-179). Although it is possible that IBS patients suffer from gluten intolerance, further studies are required to confirm this before any definitive conclusions can be drawn. Guidance on diet management, including individually tailored restrictions of FODMAP-rich foods and the testing of protein-, fat- and carbohydrate-rich/poor diets reduce IBS symptoms and accordingly improve the overall management of the health of IBS patients.

\section{References}

1. El-Salhy M, Gundersen D, Hatlebakk JG and Hausken T: Irritable bowel syndrome: diagnosis, pathogenesis and treatment options. Nova Science Publishers, Inc., New York, 2012.

2. Thompson WG: A world view of IBS. In: Irritable Bowel Syndrome. Camilleri M and Spiller RC (eds). Saunders, Philadelphia and London, pp17-26, 2002.

3. Agreus L, Svardsudd K, Nyren O and Tibblin G: Irritable bowel syndrome and dyspepsia in the general population: overlap and lack of stability over time. Gastroenterology 109: 671-680, 1995.

4. Thompson WG, Irvine EJ, Pare P, Ferrazzi S and Rance L: Functional gastrointestinal disorders in Canada: first populationbased survey using Rome II criteria with suggestions for improving the questionnaire. Dig Dis Sci 47: 225-235, 2002.

5. Kennedy TM, Jones RH, Hungin AP, O'Flanagan H and Kelly P: Irritable bowel syndrome, gastro-oesophageal reflux, and bronchial hyper-responsiveness in the general population. Gut 43: 770-774, 1998.

6. Drossman DA, Li Z, Andruzzi E, et al: U.S. householder survey of functional gastrointestinal disorders. Prevalence, sociodemography, and health impact. Dig Dis Sci 38: 1569-1580, 1993.
7. Talley NJ, Gabriel SE, Harmsen WS, Zinsmeister AR and Evans RW: Medical costs in community subjects with irritable bowel syndrome. Gastroenterology 109: 1736-1741, 1995.

8. Hungin AP, Whorwell PJ, Tack J and Mearin F: The prevalence, patterns and impact of irritable bowel syndrome: an international survey of 40,000 subjects. Aliment Pharmacol Ther 17: 643-650, 2003.

9. Jones R and Lydeard S: Irritable bowel syndrome in the general population. BMJ 304: 87-90, 1992.

10. Bordie AK: Functional disorders of the colon. J Indian Med Assoc 58: 451-456, 1972.

11. O'Keefe EA, Talley NJ, Zinsmeister AR and Jacobsen SJ: Bowel disorders impair functional status and quality of life in the elderly: a population-based study. J Gerontol A Biol Sci Med Sci 50: M184-M189, 1995.

12. Everhart JE and Renault PF: Irritable bowel syndrome in officebased practice in the United States. Gastroenterology 100: 998-1005, 1991.

13. Wilson S, Roberts L, Roalfe A, Bridge P and Singh S: Prevalence of irritable bowel syndrome: a community survey. Br J Gen Pract 54: 495-502, 2004.

14. Quigley EM, Locke GR, Mueller-Lissner S, et al: Prevalence and management of abdominal cramping and pain: a multinational survey. Aliment Pharmacol Ther 24: 411-419, 2006.

15. Harvey RF, Salih SY and Read AE: Organic and functional disorders in 2000 gastroenterology outpatients. Lancet 1: 632-634, 1983.

16. Spiller R, Aziz Q, Creed F, et al: Guidelines on the irritable bowel syndrome: mechanisms and practical management. Gut 56: 1770-1798, 2007.

17. Longstreth GF, Thompson WG, Chey WD, Houghton LA, Mearin F and Spiller RC: Functional bowel disorders. Gastroenterology 130: 1480-1491, 2006.

18. Thompson WG and Heaton KW: Functional bowel disorders in apparently healthy people. Gastroenterology 79: 283-288, 1980.

19. Miller V, Whitaker K, Morris JA and Whorwell PJ: Gender and irritable bowel syndrome: the male connection. J Clin Gastroenterol 38: 558-560, 2004.

20. Whitehead WE, Burnett CK, Cook EW III and Taub E: Impact of irritable bowel syndrome on quality of life. Dig Dis Sci 41: 2248-2253, 1996.

21. Gralnek IM, Hays RD, Kilbourne A, Naliboff B and Mayer EA: The impact of irritable bowel syndrome on health-related quality of life. Gastroenterology 119: 654-660, 2000.

22. El-Salhy M: Irritable bowel syndrome: diagnosis and pathogenesis. World J Gastroenterol 18: 5151-5163, 2012.

23. Simren M, Mansson A, Langkilde AM, et al: Food-related gastrointestinal symptoms in the irritable bowel syndrome. Digestion 63: 108-115, 2001.

24. Nanda R, James R, Smith H, Dudley CR and Jewell DP: Food intolerance and the irritable bowel syndrome. Gut 30: 1099-1104, 1989.

25. Bohn L, Storsrud S, Tornblom H, Bengtsson U and Simren M: Self-reported food-related gastrointestinal symptoms in IBS are common and associated with more severe symptoms and reduced quality of life. Am J Gastroenterol 108: 634-641, 2013.

26. Jarrett M, Heitkemper MM, Bond EF and Georges J: Comparison of diet composition in women with and without functional bowel disorder. Gastroenterol Nurs 16: 253-258, 1994.

27. Saito YA, Locke GR III, Weaver AL, Zinsmeister AR and Talley NJ: Diet and functional gastrointestinal disorders: a population-based case-control study. Am J Gastroenterol 100: 2743-2748, 2005.

28. Williams EA, Nai X and Corfe BM: Dietary intakes in people with irritable bowel syndrome. BMC Gastroenterol 11: 9, 2011.

29. Ostgaard H, Hausken T, Gundersen D and El-Salhy M: Diet and effects of diet management on quality of life and symptoms in patients with irritable bowel syndrome. Mol Med Rep 5: 1382-1390, 2012.

30. Böhn L, Störsrud S and Simrén M: Nutrient intake in patients with irritable bowel syndrome compared with the general population. Neurogastroenterol Motil 25: 23-e21, 2013.

31. Ligaarden SC, Lydersen S and Farup PG: Diet in subjects with irritable bowel syndrome: a cross-sectional study in the general population. BMC Gastroenterol 12: 61, 2012.

32. El-Salhy M, Ostgaard H, Gundersen D, Hatlebakk JG and Hausken T: The role of diet in the pathogenesis and management of irritable bowel syndrome (Review). Int J Mol Med 29: 723-731, 2012. 
33. Dizdar V, Spiller R, Singh G, et al: Relative importance of abnormalities of CCK and 5-HT (serotonin) in Giardia-induced post-infectious irritable bowel syndrome and functional dyspepsia. Aliment Pharmacol Ther 31: 883-891, 2010.

34. Monsbakken KW, Vandvik PO and Farup PG: Perceived food intolerance in subjects with irritable bowel syndrome - etiology, prevalence and consequences. Eur J Clin Nutr 60: 667-672, 2006

35. Vesa TH, Seppo LM, Marteau PR, Sahi T and Korpela R: Role of irritable bowel syndrome in subjective lactose intolerance. Am J Clin Nutr 67: 710-715, 1998.

36. Geissler C: Human Nutrition. Geissler C and Powers H (eds). Elsevier, Churchill Livingstone, 2005.

37. Wald A and Rakel D: Behavioral and complementary approaches for the treatment of irritable bowel syndrome. Nutr Clin Pract 23: 284-292, 2008

38. Heizer WD, Southern S and McGovern S: The role of diet in symptoms of irritable bowel syndrome in adults: a narrative review. J Am Diet Assoc 109: 1204-1214, 2009.

39. Morcos A, Dinan T and Quigley EM: Irritable bowel syndrome: role of food in pathogenesis and management. J Dig Dis 10 237-246, 2009.

40. Eswaran S, Tack J and Chey WD: Food: the forgotten factor in the irritable bowel syndrome. Gastroenterol Clin North Am 40: 141-162, 2011.

41. Austin GL, Dalton CB, Hu Y, et al: A very low-carbohydrate diet improves symptoms and quality of life in diarrhea-predominant irritable bowel syndrome. Clin Gastroenterol Hepatol 7: 706-708 e701, 2009.

42. Barrett JS and Gibson PR: Fermentable oligosaccharides disaccharides, monosaccharides and polyols (FODMAPs) and nonallergic food intolerance: FODMAPs or food chemicals? Therap Adv Gastroenterol 5: 261-268, 2012.

43. Barrett JS: Extending our knowledge of fermentable, short-chain carbohydrates for managing gastrointestinal symptoms. Nutr Clin Pract 28: 300-306, 2013

44. Biesiekierski JR, Rosella O, Rose R, et al: Quantification of fructans, galacto-oligosacharides and other short-chain carbohydrates in processed grains and cereals. J Hum Nutr Diet 24 154-176, 2011.

45. de Roest RH, Dobbs BR, Chapman BA, et al: The low FODMAP diet improves gastrointestinal symptoms in patients with irritable bowel syndrome: a prospective study. Int J Clin Pract 67: 895-903, 2013.

46. Staudacher HM, Whelan K, Irving PM and Lomer MC: Comparison of symptom response following advice for a diet low in fermentable carbohydrates (FODMAPs) versus standard dietary advice in patients with irritable bowel syndrome. J Hum Nutr Diet 24: 487-495, 2011.

47. Bijkerk CJ, Muris JW, Knottnerus JA, Hoes AW and de Wit NJ: Systematic review: the role of different types of fibre in the treatment of irritable bowel syndrome. Aliment Pharmacol Ther 19: 245-251, 2004

48. Ford AC, Talley NJ, Spiegel BM, et al: Effect of fibre, antispasmodics, and peppermint oil in the treatment of irritable bowel syndrome: systematic review and meta-analysis. BMJ 337: a2313, 2008.

49. Francis $\mathrm{CY}$ and Whorwell PJ: Bran and irritable bowel syndrome: time for reappraisal. Lancet 344: 39-40, 1994.

50. Bijkerk CJ, de Wit NJ, Muris JW, Whorwell PJ, Knottnerus JA and Hoes AW: Soluble or insoluble fibre in irritable bowel syndrome in primary care? Randomised placebo controlled trial. BMJ 339: b3154, 2009.

51. Kassinen A, Krogius-Kurikka L, Makivuokko H, et al: The fecal microbiota of irritable bowel syndrome patients differs significantly from that of healthy subjects. Gastroenterology 133 24-33, 2007.

52. Si JM, Yu YC, Fan YJ and Chen SJ: Intestinal microecology and quality of life in irritable bowel syndrome patients. World J Gastroenterol 10: 1802-1805, 2004.

53. El-Salhy M, Seim I, Chopin L, Gundersen D, Hatlebakk JG and Hausken T: Irritable bowel syndrome: the role of gut neuroendocrine peptides. Front Biosci (Elite Ed) 4: 2783-2800, 2012.

54. Gunawardene AR, Corfe BM and Staton CA: Classification and functions of enteroendocrine cells of the lower gastrointestinal tract. Int J Exp Pathol 92: 219-231, 2011.

55. May CL and Kaestner KH: Gut endocrine cell development. Mol Cell Endocrinol 323: 70-75, 2010.

56. Mawe GM, Coates MD and Moses PL: Review article: intestinal serotonin signalling in irritable bowel syndrome. Aliment Pharmacol Ther 23: 1067-1076, 2006.
57. Wade PR, Chen J, Jaffe B, Kassem IS, Blakely RD and Gershon MD: Localization and function of a 5-HT transporter in crypt epithelia of the gastrointestinal tract. J Neurosci 16: 2352-2364, 1996.

58. Gershon MD and Tack J: The serotonin signaling system: from basic understanding to drug development for functional GI disorders. Gastroenterology 132: 397-414, 2007.

59. Gershon MD: 5-Hydroxytryptamine (serotonin) in the gastrointestinal tract. Curr Opin Endocrinol Diabetes Obes 20: 14-21, 2013.

60. Gershon MD: Serotonin is a sword and a shield of the bowel serotonin plays offense and defense. Trans Am Clin Climatol Assoc 123: 268-280, 2012.

61. El-Salhy M, Mazzawi T, Gundersen D, Hatlebakk JG and Hausken T: The role of peptide YY in gastrointestinal diseases and disorders (Review). Int J Mol Med 31: 275-282, 2013

62. Dubrasquet M, Bataille D and Gespach C: Oxyntomodulin (glucagon-37 or bioactive enteroglucagon): a potent inhibitor of pentagastrin-stimulated acid secretion in rats. Biosci Rep 2: 391-395, 1982.

63. Schjoldager BT, Baldissera FG, Mortensen PE, Holst JJ and Christiansen J: Oxyntomodulin: a potential hormone from the distal gut. Pharmacokinetics and effects on gastric acid and insulin secretion in man. Eur J Clin Invest 18: 499-503, 1988

64. Schjoldager B, Mortensen PE, Myhre J, Christiansen J and Holst JJ: Oxyntomodulin from distal gut. Role in regulation of gastric and pancreatic functions. Dig Dis Sci 34: 1411-1419, 1989.

65. Dakin CL, Small CJ, Batterham RL, et al: Peripheral oxyntomodulin reduces food intake and body weight gain in rats. Endocrinology 145: 2687-2695, 2004.

66. Wynne K, Park AJ, Small CJ, et al: Subcutaneous oxyntomodulin reduces body weight in overweight and obese subjects: a doubleblind, randomized, controlled trial. Diabetes 54: 2390-2395, 2005.

67. Camilleri M: Peripheral mechanisms in irritable bowel syndrome. N Engl J Med 367: 1626-1635, 2012

68. Jianu CS, Fossmark R, Syversen U, Hauso O and Waldum HL: A meal test improves the specificity of chromogranin A as a marker of neuroendocrine neoplasia. Tumour Biol 31: 373-380, 2010.

69. Sandstrom O and El-Salhy M: Ageing and endocrine cells of human duodenum. Mech Ageing Dev 108: 39-48, 1999.

70. El-Salhy M: Ghrelin in gastrointestinal diseases and disorders: a possible role in the pathophysiology and clinical implications (Review). Int J Mol Med 24: 727-732, 2009.

71. Tolhurst G, Reimann F and Gribble FM: Intestinal sensing of nutrients. Handb Exp Pharmacol: 309-335, 2012

72. Lee J, Cummings BP, Martin E, et al: Glucose sensing by gut endocrine cells and activation of the vagal afferent pathway is impaired in a rodent model of type 2 diabetes mellitus. Am J Physiol Regul Integr Comp Physiol 302: R657-R666, 2012.

73. Parker HE, Reimann F and Gribble FM: Molecular mechanisms underlying nutrient-stimulated incretin secretion. Expert Rev Mol Med 12: e1, 2010.

74. Raybould HE: Nutrient sensing in the gastrointestinal tract: possible role for nutrient transporters. J Physiol Biochem 64: 349-356, 2008

75. San Gabriel A, Nakamura E, Uneyama H and Torii K: Taste, visceral information and exocrine reflexes with glutamate through umami receptors. J Med Invest 56 (Suppl): S209-S217, 2009.

76. Rudholm T, Wallin B, Theodorsson E, Naslund E and Hellstrom PM: Release of regulatory gut peptides somatostatin, neurotensin and vasoactive intestinal peptide by acid and hyperosmolal solutions in the intestine in conscious rats. Regul Pept 152: 8-12, 2009.

77. Sternini C, Anselmi L and Rozengurt E: Enteroendocrine cells: a site of 'taste' in gastrointestinal chemosensing. Curr Opin Endocrinol Diabetes Obes 15: 73-78, 2008.

78. Sternini C: Taste receptors in the gastrointestinal tract. IV. Functional implications of bitter taste receptors in gastrointestinal chemosensing. Am J Physiol Gastrointest Liver Physiol 292: G457-G461, 2007.

79. Buchan AM: Nutrient Tasting and Signaling Mechanisms in the Gut III. Endocrine cell recognition of luminal nutrients. Am J Physiol 277: G1103-G1107, 1999.

80. Montero-Hadjadje M, Elias S, Chevalier L, et al: Chromogranin A promotes peptide hormone sorting to mobile granules in constitutively and regulated secreting cells: role of conserved $\mathrm{N}$ - and C-terminal peptides. J Biol Chem 284: 12420-12431, 2009.

81. Shooshtarizadeh P, Zhang D, Chich JF, et al: The antimicrobial peptides derived from chromogranin/secretogranin family, new actors of innate immunity. Regul Pept 165: 102-110, 2010. 
82. Rindi G, Inzani F and Solcia E: Pathology of gastrointestinal disorders. Endocrinol Metab Clin North Am 39: 713-727, 2010.

83. Seim I, El-Salhy M, Hausken T, Gundersen D and Chopin L: Ghrelin and the brain-gut axis as a pharmacological target for appetite control. Curr Pharm Des 18: 768-775, 2012.

84. Wendelbo I, Mazzawi T and El-Salhy M: Increased serotonin transporter immunoreactivity intensity in the ileum of patients with irritable bowel disease. Mol Med Rep 9: 180-184, 2014.

85. El-Salhy M, Wendelbo IH and Gundersen D: Reduced chromogranin A cell density in the ileum of patients with irritable bowel syndrome. Mol Med Rep 7: 1241-1244, 2013.

86. El-Salhy M, Vaali K, Dizdar V and Hausken T: Abnorma small-intestinal endocrine cells in patients with irritable bowel syndrome. Dig Dis Sci 55: 3508-3513, 2010.

87. El-Salhy M, Mazzawi T, Gundersen D and Hausken T: Chromogranin A cell density in the rectum of patients with irritable bowel syndrome. Mol Med Rep 6: 1223-1225, 2012.

88. El-Salhy M, Lomholt-Beck B and Hausken T: Chromogranin A as a possible tool in the diagnosis of irritable bowel syndrome. Scand J Gastroenterol 45: 1435-1439, 2010.

89. El-Salhy M, Lillebo E, Reinemo A and Salmelid L: Ghrelin in patients with irritable bowel syndrome. Int J Mol Med 23: 703-707, 2009.

90.El-Salhy M, Hatlebakk JG, Gundersen D and Hausken T: Endocrine cells in the gastric oxyntic mucosa of patients with irritable bowel syndrome. Dig Dis Sci, 2013.

91. El-Salhy M, Gundersen D, Ostgaard H, Lomholt-Beck B, Hatlebakk JG and Hausken T: Low densities of serotonin and peptide YY cells in the colon of patients with irritable bowel syndrome. Dig Dis Sci 57: 873-878, 2012.

92.El-Salhy M, Gundersen D, Hatlebakk JG and Hausken T: Chromogranin a cell density as a diagnostic marker for lymphocytic colitis. Dig Dis Sci 57: 3154-3159, 2012.

93. El-Salhy M, Gundersen D, Hatlebakk JG and Hausken T: Gastric endocrine cells in the oxyntic mucosa ofpatients with irritable bowel syndrome. Dig Dis Sci, 2013.

94.El-Salhy M, Gilja OH, Hatlebakk JG and Hausken T: Gastric antral endocrine cells in patients with irritable bowel syndrome. BMC Gastroenterol, 2013

95. El-Salhy M, Gilja OH and Hausken T: Chromogranin A cells in the stomach of patients with sporadic irritable bowel syndrome. Histol Histopathol, 2013

96. Sjolund K, Ekman R and Wierup N: Covariation of plasma ghrelin and motilin in irritable bowel syndrome. Peptides 31 $1109-1112,2010$.

97. Wang SH, Dong L, Luo JY, et al: Decreased expression of serotonin in the jejunum and increased numbers of mast cells in the terminal ileum in patients with irritable bowel syndrome. World J Gastroenterol 13: 6041-6047, 2007.

98. Park JH, Rhee PL, Kim G, et al: Enteroendocrine cell counts correlate with visceral hypersensitivity in patients with diarrhoeapredominant irritable bowel syndrome. Neurogastroenterol Motil 18: 539-546, 2006.

99. Coates MD, Mahoney CR, Linden DR, et al: Molecular defects in mucosal serotonin content and decreased serotonin reuptake transporter in ulcerative colitis and irritable bowel syndrome. Gastroenterology 126: 1657-1664, 2004.

100.El-Salhy M, Wendelbo I and Gundersen D: Serotonin and serotonin transporter in the rectum of patients with irritable bowel disease. Mol Med Rep 8: 451-455, 2013.

101. Hotoleanu C, Popp R, Trifa AP, Nedelcu L and Dumitrascu DL: Genetic determination of irritable bowel syndrome. World J Gastroenterol 14: 6636-6640, 2008.

102. Whorwell PJ, McCallum M, Creed FH and Roberts CT: Non-colonic features of irritable bowel syndrome. Gut 27 $37-40,1986$

103. Locke GR III, Zinsmeister AR, Talley NJ, Fett SL and Melton LJIII: Familial association in adults with functional gastrointestinal disorders. Mayo Clin Proc 75: 907-912, 2000.

104. Kalantar JS, Locke GR III, Zinsmeister AR, Beighley CM and Talley NJ: Familial aggregation of irritable bowel syndrome: a prospective study. Gut 52: 1703-1707, 2003.

105. Kanazawa M, Endo Y, Whitehead WE, Kano M, Hongo M and Fukudo S: Patients and nonconsulters with irritable bowel syndrome reporting a parental history of bowel problems have more impaired psychological distress. Dig Dis Sci 49: 1046-1053, 2004.

106. Morris-Yates A, Talley NJ, Boyce PM, Nandurkar S and Andrews G: Evidence of a genetic contribution to functional bowel disorder. Am J Gastroenterol 93: 1311-1317, 1998.
107. Levy RL, Jones KR, Whitehead WE, Feld SI, Talley NJ and Corey LA: Irritable bowel syndrome in twins: heredity and social learning both contribute to etiology. Gastroenterology 121 : 799-804, 2001

108. Lembo A, Zaman M, Jones M and Talley NJ: Influence of genetics on irritable bowel syndrome, gastro-oesophageal reflux and dyspepsia: a twin study. Aliment Pharmacol Ther 25: 1343-1350, 2007.

109. Wojczynski MK, North KE, Pedersen NL and Sullivan PF: Irritable bowel syndrome: a co-twin control analysis. Am J Gastroenterol 102: 2220-2229, 2007.

110. Bengtson MB, Ronning T, Vatn MH and Harris JR: Irritable bowel syndrome in twins: genes and environment. Gut 55: 1754-1759, 2006.

111. Mohammed I, Cherkas LF, Riley SA, Spector TD and Trudgill NJ: Genetic influences in irritable bowel syndrome: a twin study. Am J Gastroenterol 100: 1340-1344, 2005.

112. Akiho H, Ihara E and Nakamura K: Low-grade inflammation plays a pivotal role in gastrointestinal dysfunction in irritable bowel syndrome. World J Gastrointest Pathophysiol 1: 97-105, 2010.

113. Wouters MM and Boeckxstaens GE: Neuroimmune mechanisms in functional bowel disorders. Neth J Med 69: 55-61, 2011.

114. Kuwahara A, Kuramoto H and Kadowaki M: 5-HT activates nitric oxide-generating neurons to stimulate chloride secretion in guinea pig distal colon. Am J Physiol 275: G829-G834, 1998

115. Gershon MD: Plasticity in serotonin control mechanisms in the gut. Curr Opin Pharmacol 3: 600-607, 2003.

116. Zar S, Benson MJ and Kumar D: Food-specific serum IgG4 and IgE titers to common food antigens in irritable bowel syndrome. Am J Gastroenterol 100: 1550-1557, 2005.

117. Zar S, Kumar D and Benson MJ: Food hypersensitivity and irritable bowel syndrome. Aliment Pharmacol Ther 15: 439-449, 2001.

118. Park MI and Camilleri M: Is there a role of food allergy in irritable bowel syndrome and functional dyspepsia? A systematic review. Neurogastroenterol Motil 18: 595-607, 2006.

119. Uz E, Turkay C, Aytac S and Bavbek N: Risk factors for irritable bowel syndrome in Turkish population: role of food allergy. J Clin Gastroenterol 41: 380-383, 2007.

120. Dainese R, Galliani EA, De Lazzari F, Di Leo V and Naccarato R Discrepancies between reported food intolerance and sensitization test findings in irritable bowel syndrome patients. Am J Gastroenterol 94: 1892-1897, 1999.

121. Bischoff S and Crowe SE: Gastrointestinal food allergy: new insights into pathophysiology and clinical perspectives. Gastroenterology 128: 1089-1113, 2005.

122. Murch S: Allergy and intestinal dysmotility--evidence of genuine causal linkage? Curr Opin Gastroenterol 22: 664-668, 2006.

123. Gui XY: Mast cells: a possible link between psychological stress, enteric infection, food allergy and gut hypersensitivity in the irritable bowel syndrome. J Gastroenterol Hepatol 13: 980-989, 1998.

124. Teufel M, Biedermann T, Rapps N, et al: Psychological burden of food allergy. World J Gastroenterol 13: 3456-3465, 2007.

125. Walker MM and Talley NJ: Functional gastrointestinal disorders and the potential role of eosinophils. Gastroenterol Clin North Am 37: 383-395, vi, 2008.

126. Petitpierre M, Gumowski P and Girard JP: Irritable bowel syndrome and hypersensitivity to food. Ann Allergy 54: 538-540, 1985.

127. Tobin MC, Moparty B, Farhadi A, DeMeo MT, Bansal PJ and Keshavarzian A: Atopic irritable bowel syndrome: a novel subgroup of irritable bowel syndrome with allergic manifestations. Ann Allergy Asthma Immunol 100: 49-53, 2008.

128. Atkinson W, Sheldon TA, Shaath N and Whorwell PJ: Food elimination based on IgG antibodies in irritable bowel syndrome: a randomised controlled trial. Gut 53: 1459-1464, 2004

129. Whorwell PJ: The growing case for an immunological component to irritable bowel syndrome. Clin Exp Allergy 37: 805-807, 2007.

130. Hunter JO: Food elimination in IBS: the case for IgG testing remains doubtful. Gut 54: 1203; author reply 1203, 2005.

131. Beyer K and Teuber SS: Food allergy diagnostics: scientific and unproven procedures. Curr Opin Allergy Clin Immunol 5: 261-266, 2005.

132. Choung RS, Branda ME, Chitkara D, et al: Longitudinal direct medical costs associated with constipation in women. Aliment Pharmacol Ther 33: 251-260, 2011. 
133. Ortolani C, Bruijnzeel-Koomen C, Bengtsson U, et al: Controversial aspects of adverse reactions to food. European Academy of Allergology and Clinical Immunology (EAACI) Reactions to Food Subcommittee. Allergy 54: 27-45, 1999.

134. Frissora CL and Koch KL: Symptom overlap and comorbidity of irritable bowel syndrome with other conditions. Curr Gastroenterol Rep 7: 264-271, 2005.

135. El-Salhy M, Lomholt-Beck B and Gundersen D: The prevalence of celiac disease in patients with irritable bowel syndrome. Mol Med Rep 4: 403-405, 2011.

136. Catassi C, Kryszak D, Louis-Jacques O, et al: Detection of Celiac disease in primary care: a multicenter case-finding study in North America. Am J Gastroenterol 102: 1454-1460, 2007.

137. Fasano A, Berti I, Gerarduzzi T, et al: Prevalence of celiac disease in at-risk and not-at-risk groups in the United States: a large multicenter study. Arch Intern Med 163: 286-292, 2003.

138. van der Wouden EJ, Nelis GF and Vecht J: Screening for coeliac disease in patients fulfilling the Rome II criteria for irritable bowel syndrome in a secondary care hospital in The Netherlands: a prospective observational study. Gut 56: 444-445, 2007.

139. Locke GR III, Murray JA, Zinsmeister AR, Melton LJ III and Talley NJ: Celiac disease serology in irritable bowel syndrome and dyspepsia: a population-based case-control study. Mayo Clin Proc 79: 476-482, 2004.

140. Hin H, Bird G, Fisher P, Mahy N and Jewell D: Coeliac disease in primary care: case finding study. BMJ 318: 164-167, 1999.

141. Shahbazkhani B, Forootan M, Merat S, et al: Coeliac disease presenting with symptoms of irritable bowel syndrome. Aliment Pharmacol Ther 18: 231-235, 2003.

142. Korkut E, Bektas M, Oztas E, Kurt M, Cetinkaya H and Ozden A: The prevalence of celiac disease in patients fulfilling Rome III criteria for irritable bowel syndrome. Eur J Intern Med 21: 389-392, 2010.

143. Sanders DS, Patel D, Stephenson TJ, et al: A primary care cross-sectional study of undiagnosed adult coeliac disease. Eur J Gastroenterol Hepatol 15: 407-413, 2003.

144. Verdu EF, Armstrong D and Murray JA: Between celiac disease and irritable bowel syndrome: the 'no man's land' of gluten sensitivity. Am J Gastroenterol 104: 1587-1594, 2009.

145. Wahnschaffe U, Schulzke JD, Zeitz M and Ullrich R: Predictors of clinical response to gluten-free diet in patients diagnosed with diarrhea-predominant irritable bowel syndrome. Clin Gastroenterol Hepatol 5: 844-850; quiz 769, 2007.

146. Carroccio A, Mansueto P, Iacono G, et al: Non-celiac wheat sensitivity diagnosed by double-blind placebo-controlled challenge: exploring a new clinical entity. Am J Gastroenterol 107: 1898-1906; quiz 1907, 2012.

147. Aziz I and Sanders DS: Emerging concepts: from coeliac disease to non-coeliac gluten sensitivity. Proc Nutr Soc 71: 576-580, 2012.

148. Newnham ED: Does gluten cause gastrointestinal symptoms in subjects without coeliac disease? J Gastroenterol Hepatol 26 (Suppl 3): S132-S134, 2011.

149. Biesiekierski JR, Peters SL, Newnham ED, Rosella O, Muir JG and Gibson PR: No effects of gluten in patients with selfreported non-celiac gluten sensitivity after dietary reduction of fermentable, poorly absorbed, short-chain carbohydrates. Gastroenterology 145: 320-328 e323, 2013

150. Mazzawi T, Hausken T, Gundersen D and El-Salhy M: Effects of dietary guidance on the symptoms, quality of life and habitual dietary intake of patients with irritable bowel syndrome. Mol Med Rep 8: 845-852, 2013.

151. El-Salhy M, Lilbo E, Reinemo A, Salmeøid L and Hausken T: Effects of a health program comprising reassurance, diet management, probiotic administration and regular exercise on symptoms and quality of life in patients with irritable bowel syndrome. Gastroenterol Insights 2: 21-26, 2010.

152. Posserud I, Syrous A, Lindstrom L, Tack J, Abrahamsson H and Simren M: Altered rectal perception in irritable bowel syndrome is associated with symptom severity. Gastroenterology 133: 1113-1123, 2007.

153. Ritchie J: Pain from distension of the pelvic colon by inflating a balloon in the irritable colon syndrome. Gut 14: 125-132, 1973.

154. Mertz H, Naliboff B, Munakata J, Niazi N and Mayer EA: Altered rectal perception is a biological marker of patients with irritable bowel syndrome. Gastroenterology 109: 40-52, 1995.

155. Whitehead WE and Palsson OS: Is rectal pain sensitivity a biological marker for irritable bowel syndrome: psychological influences on pain perception. Gastroenterology 115: 1263-1271, 1998.
156. Whitehead WE, Holtkotter B, Enck P, et al: Tolerance for rectosigmoid distention in irritable bowel syndrome. Gastroenterology 98: 1187-1192, 1990.

157. Bouin M, Plourde V, Boivin M, et al: Rectal distention testing in patients with irritable bowel syndrome: sensitivity, specificity, and predictive values of pain sensory thresholds. Gastroenterology 122: 1771-1777, 2002.

158. Bradette M, Delvaux M, Staumont G, Fioramonti J, Bueno L and Frexinos J: Evaluation of colonic sensory thresholds in IBS patients using a barostat. Definition of optimal conditions and comparison with healthy subjects. Dig Dis Sci 39: 449-457, 1994.

159. Camilleri M, McKinzie S, Busciglio I, et al: Prospective study of motor, sensory, psychologic, and autonomic functions in patients with irritable bowel syndrome. Clin Gastroenterol Hepatol 6: 772-781, 2008

160. Costantini M, Sturniolo GC, Zaninotto G, et al: Altered esophageal pain threshold in irritable bowel syndrome. Dig Dis Sci 38: 206-212, 1993.

161. Trimble KC, Farouk R, Pryde A, Douglas S and Heading RC: Heightened visceral sensation in functional gastrointestinal disease is not site-specific. Evidence for a generalized disorder of gut sensitivity. Dig Dis Sci 40: 1607-1613, 1995.

162. Zighelboim J, Talley NJ, Phillips SF, Harmsen WS and Zinsmeister AR: Visceral perception in irritable bowel syndrome. Rectal and gastric responses to distension and serotonin type 3 antagonism. Dig Dis Sci 40: 819-827, 1995.

163. Accarino AM, Azpiroz F and Malagelada JR: Selective dysfunction of mechanosensitive intestinal afferents in irritable bowel syndrome. Gastroenterology 108: 636-643, 1995.

164. Kanazawa M, Hongo M and Fukudo S: Visceral hypersensitivity in irritable bowel syndrome. J Gastroenterol Hepatol 26 (Suppl 3): S119-S121, 2011.

165. Whorwell PJ, Clouter C and Smith CL: Oesophageal motility in the irritable bowel syndrome. Br Med J (Clin Res Ed) 282: $1101-1102,1981$.

166. Clouse RE and Eckert TC: Gastrointestinal symptoms of patients with esophageal contraction abnormalities. Dig Dis Sci 31: 236-240, 1986.

167. Soffer EE, Scalabrini P, Pope CE II and Wingate DL: Effect of stress on oesophageal motor function in normal subjects and in patients with the irritable bowel syndrome. Gut 29: 1591-1594, 1988.

168. Lind CD: Motility disorders in the irritable bowel syndrome. Gastroenterol Clin North Am 20: 279-295, 1991.

169. Lee OY: Asian motility studies in irritable bowel syndrome. J Neurogastroenterol Motil 16: 120-130, 2010.

170. van Wijk HJ, Smout AJ, Akkermans LM, Roelofs JM and ten Thije OJ: Gastric emptying and dyspeptic symptoms in the irritable bowel syndrome. Scand J Gastroenterol 27: 99-102, 1992.

171. Charles F, Phillips SF, Camilleri M and Thomforde GM: Rapid gastric emptying in patients with functional diarrhea. Mayo Clin Proc 72: 323-328, 1997.

172. Caballero-Plasencia AM, Valenzuela-Barranco M, HerreriasGutierrez JM and Esteban-Carretero JM: Altered gastric emptying in patients with irritable bowel syndrome. Eur J Nucl Med 26: 404-409, 1999.

173. Portincasa P, Moschetta A, Baldassarre G, Altomare DF and Palasciano G: Pan-enteric dysmotility, impaired quality of life and alexithymia in a large group of patients meeting ROME II criteria for irritable bowel syndrome. World J Gastroenterol 9: 2293-2299, 2003.

174. Stanghellini V, Tosetti C, Barbara G, et al: Dyspeptic symptoms and gastric emptying in the irritable bowel syndrome. Am J Gastroenterol 97: 2738-2743, 2002.

175. Leahy A, Besherdas K, Clayman C, Mason I and Epstein O: Abnormalities of the electrogastrogram in functional gastrointestinal disorders. Am J Gastroenterol 94: 1023-1028, 1999.

176. Evans PR, Bak YT, Shuter B, Hoschl R and Kellow JE: Gastroparesis and small bowel dysmotility in irritable bowel syndrome. Dig Dis Sci 42: 2087-2093, 1997.

177. Nielsen $\mathrm{OH}$, Gjorup T and Christensen FN: Gastric emptying rate and small bowel transit time in patients with irritable bowel syndrome determined with $99 \mathrm{mTc}$-labeled pellets and scintigraphy. Dig Dis Sci 31: 1287-1291, 1986.

178. Narducci F, Bassotti G, Granata MT, et al: Colonic motility and gastric emptying in patients with irritable bowel syndrome. Effect of pretreatment with octylonium bromide. Dig Dis Sci 31: 241-246, 1986.

179. Acharya U, Waite N, Howlett P, Tanner AR and Smith CL: Failure to demonstrate altered gastric emptying in irritable bowel syndrome. Dig Dis Sci 28: 889-892, 1983. 